\title{
LAND USE CHANGE AND DETERIORATION OF PHARAONIC MONUMENTS IN UPPER EGYPT
}

\author{
Ayman A. Ahmed \\ Geology Department, Faculty of Science, Sohag University, Sohag, Egypt \\ Email: ayman ahmed02@yahoo.com
}

(Received December 6, 2008 Accepted January 25, 2009)

\begin{abstract}
Pharaonic monuments in Upper Egypt are currently threatened by environmental impacts including the rise of groundwater table, seepage of drainage and sewage water from cultivated lands and surrounding houses as well as salinity problems. These problems are mainly due to change of land use since construction of High Dam in 1968. land use changes include expansion of old cultivated lands, expansion of urban areas, as well as change of irrigation. The present paper uses techniques of geographic information systems and remotely sensed data for determination of land use change in Upper Egypt since construction of High Dam. The study depends on using Landsat imagery covering the period 1972 - 2000. Results of this study revealed that agriculture and urbanization were changed considerably during the studied period of time. Agriculture decreased from 1984 to 2000, whereas urbanization increased considerably from 1972 to 2000. These changes are accompanied by changes in environmental hazards including seepage of drainage water as well as sewage water. Management alternatives are required to make a balance between the land use changes and accompanied risks.
\end{abstract}

KEYWORDS: Land use change, Remote sensing, GIS, Landsat MSS, TM, ETM+, SRTM, Pharaonic Monuments, Luxor, Egypt.

\section{INTRODUCTION}

Pharaonic monuments represent the most valuable source of ancient Egypt, covering the period of approximately 3000 B.C. to 300 B. C. Modern civilization has resulted in rapid social, agricultural and industrial development in Egypt.

Before construction of Aswan High Dam, the agriculture cycle depended on the summer floods, and the year was divided into three seasons: the season of inundation, the season of drought when the Nile is at its lowest level and the inbetween season. In July, the main flood discharge would begin with a crest of reddishbrown muddy water from the highlands of Ethiopia. By the middle of August, the inundation would reach its peak. By the end of October, the inundation waned, and water began to subside, with the Nile sinking t its lowest level by May. Then from May to September, the rise of flood water could reach as much as 7 meters. Today, the flow of the Nile is regulated by the Aswan High Dam (Hassan, 2005).

Since completion of the Aswan High Dam (AHD) in 1970, some environmental effects have been observed in the Nile Valley, including drainage 
problems due to rising water table, soil salinization, and groundwater contamination. An important consequence of the rising groundwater levels and soil salinity is deterioration of monuments (Saleh, 1982, 1983; SWECO, 1982; Abd El Hady and Ismaeil, 1995; Ismaeil and El-Habaak, 1995, RIGW, 1997a, Ismaeil 1999 and Ismaeil and Abdel Moneim, 1999).

Due to growing population, agricultural land and urbanization moved closer to ancient temples and funeral monuments.

Karnak, Luxor temples represent the monuments of the east bank of Thebes, the old capital of Egypt. These monuments are the most important Pharaonic temples in Ancient Egypt. They are a real record of history and civilization of Egypt from the Middle Kingdom to the reign of Ptolemies (Baines and Malek, 2000). Most of the historical buildings in Upper Egypt were partially or completely built from sandstone transported from local quarries (Abdel Hady, 1986, 1988). The temples are exposed to deterioration in the form of disintegration and exfoliation of sandstone, dissolution of building materials and crystallization of salts (Ismaeil and Abdel Moneim, 1999; Ahmed, 2003)

The conditions of these sites are becoming progressively worse and urgent measures are needed to avoid the loss of this heritage. The monuments are in danger due to the impact of urban growth with houses and urban developmental projects, industrial and agricultural activities. Most environmental threats are caused by pollution, housing, rise of groundwater levels contaminated with sewage. The impact of leakage from irrigation canals and drains leads to rising groundwater levels underneath the monuments.

At Luxor, the groundwater level is continuously increasing. The increase in groundwater level caused drainage problems and high rates of evaporation from the capillary zone leading to salinization problems which in turn lead to deterioration of the monuments (SWECO, 1982; Helmy and El Shahat, 1996 RIGW, 1997a; Ismaeil, 1999; Ismaeil and Abdel Moneim, 1999; Selim et al. 2000; Ismail et al. 2005 and Ahmed, 2003).

The present study aims at identifying the land use change at Luxor area since 1972 to 2000 and its impact on the archaeological sites. The study depends on using techniques of geographic information systems and remote sensing. Landsat imagery covering the study area acquired on 1972 to 2000 were used.

\section{METHODOLOGY STUDY AREA}

Luxor City was the ancient capital of Egypt during the New Pharaoh Kingdom (15671085 B.C.). Luxor and Karnak Temples represent the largest open museums in the world at the eastern bank of the River Nile. The great temple complex of Karnak lies 3 $\mathrm{km}$ northeast of Luxor within the area of ancient Thebes, near the modern village of Karnak. Within its precincts are the Great Temple of Amun, the Temple of Khons and the Festival Temple of Tuthmosis III, as well as many other buildings. The number and preservation of the monuments in the Luxor area are unparalleled anywhere else in the world. Luxor has a remarkable history which has weaned itself and given the place a unique rich feel that has interspersed its contours with temples and tombs. The city was 
originally a part of Thebes, the Southern City, almost eight hundred kilometers south of the Mediterranean, on the east bank of the river Nile. The city was an erstwhile capital of the Egyptian world during the reign of the eleventh dynasty and also most of the eighteenth dynasty of the Egyptian Pharaohs.

The study area is located between Latitudes $25^{\circ} 40^{\prime}$ to $25^{\circ} 45^{\prime}$ and Longitudes $32^{\circ} 35^{\prime}$ and $32^{\circ} 45^{\prime}$ (Fig. 1).

\section{Legend}
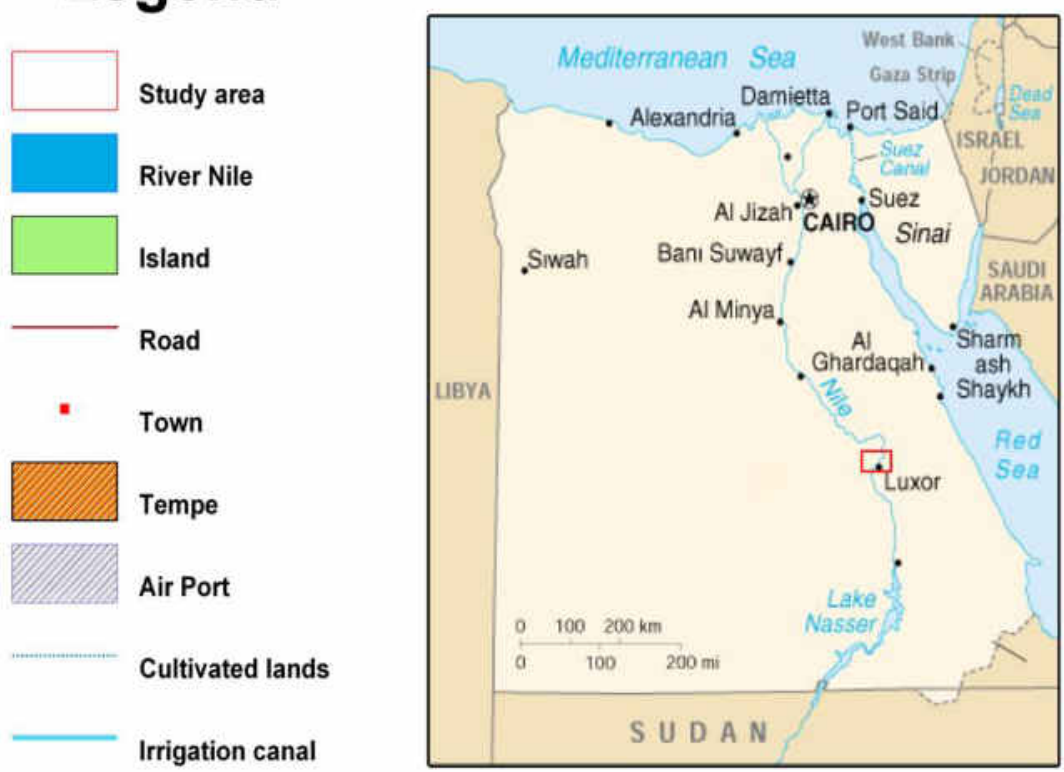

$32^{\circ} 35^{\circ} 0^{\prime \prime}$ E $32^{\circ} 36^{\prime} 0^{\prime \prime}$ E $32^{\circ} 37^{\prime} 0^{\prime \prime}$ E $32^{\circ} 38^{\circ} 0^{\prime \prime}$ E $32^{\circ} 39^{\prime} 0^{\prime \prime}$ E $32^{\circ} 40^{\prime} 0^{\prime \prime}$ E $32^{\circ} 41^{\circ} 0^{\prime \prime}$ E $32^{\circ} 42^{\circ} 0^{\circ}$ "E $32^{\circ} 43^{\circ} 0^{\prime \prime}$ E $32^{\circ} 44^{\prime} 0^{\prime \prime}$ E $32^{\circ} 45^{\circ} 0^{\circ}$ "E

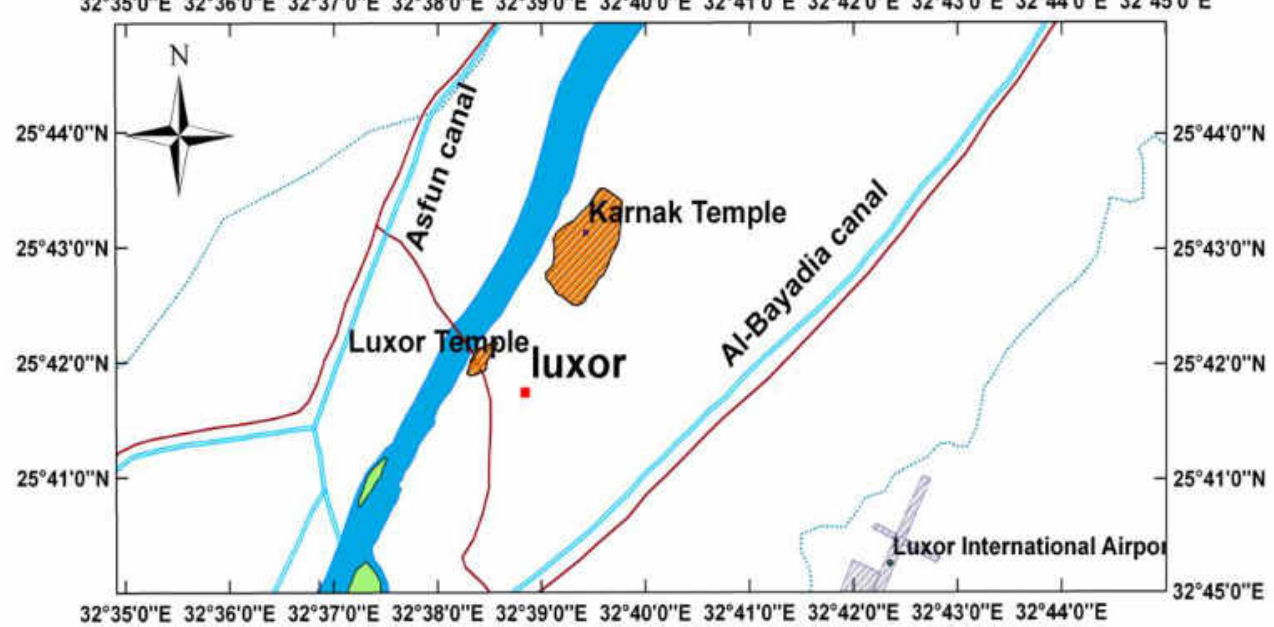

$00.51 \quad 2 \quad 3 \quad 4$

Kilometers

Fig. 1 Location map of study area. 


\section{GEOLOGIC AND HYDROGEOLOGIC SETTING}

The sedimentological succession of the study area is represented by Upper Cretaceous, Paleocene-Eocene, Pliocene, Pleistocene and Holocene sediments (Fig. 2a). Geologic setting of study area was dealt with by works of Beadnell, 1905; Cuvillier, 1938; Youssef, 1949, 1957; Ghorab, 1956; Said 1960, 1961, 1962, 1981; El-Naggar 1963, 1966, 1968; Awad and Ghobrial 1965; Butzer and Hansen, 1968; De Heinzelin, 1968; Philobbos, 1969; Ghanem et al., 1970; Wendorf and Schild, 1976; and Kamel, 2004 which can be summarized as follows:

\section{Upper Cretaceous sediments}

Sediments of Upper Cretaceous include Quseir Formation (thin bedded and highly variegated color shales, siltstones and sandstone), Duwi Formation (a sequence of alternating beds of claystone, sandstone, siltstone and oyster limestone, intercalated with phosphate and phosphatic beds), and Dakhla Formation (dark grey papery shale and marl with interbedded siltstone, sandstone and limestone).

\section{Paleocene-Eocene sediments}

Sediments of Paleocene-Eocene include Tarawan Formation (carbonate unit overlying the Dakhla Formation and underlying Esna Formation), Esna Formation (laminated green and grey shale), and Thebes Formation (limestone with flint bands).

\section{Pliocene and Pleistocene-Holocene sediments (Quaternary)}

These sediments rest unconformably on the older sediments and which was deposited by the modern river system including the Eonile (Tmu), Paleonile (Tplu), Protonile (Q1), Prenile (Q2) and Neonile (Q3) river systems (Said 1981).

The surface water hydrology of the area is mainly represented by the River Nile and irrigation canals.

Groundwater aquifers at Luxor area include the shallow Quaternary aquifer and the underlying Plio-Pleistocene aquifer (Fig. 3).

The Quaternary sediments comprise the major aquifer system in the Nile Valley which occupy the central strip of the Nile Valley and underlie cultivated lands on both sides of the Nile flood plain. It is composed of Pleistocene sand and gravel with thin interbeds of clay. The aquifer is capped by a Holocene clay layer (Awad et al, 1997). The Holocene clay layer is laterally extensive having greater thickness near the river channel and vanishing near the valley fringes where it is overlain by the desert sands. The lower layer, the Pleistocene sand and gravel, forms the main aquifer having relatively high hydraulic conductivity (Farrag, 1982). The aquifer configuration makes the system behaves as a semi-confined at the middle of the valley and unconfined at the valley fringes where the clay layer vanishes. The aquifer recharge is mainly due to applied irrigation, seepage from surface water conveyance system, occasional rainfall and subsurface inflow across external boundaries. The aquifer discharge includes flow to the River Nile, groundwater extraction and evapotranspiration (shahin, 1991). The regional groundwater flow direction is east to west towards the River Nile (El Hossary 1994). 
The underlying Plio-Pleistocene aquifer is composed of sand, clay and gravel represent the secondary aquifer in the study area which is exposed at the valley fringes (Ismail et al. 2005)

\section{$32^{\circ} 25^{\prime} 0^{\prime \prime}$ E $32^{\circ} 30^{\prime} 0^{\prime \prime E} 32^{\circ} 35^{\prime} 0^{\prime \prime E ~} 32^{\circ} 40^{\prime} 0^{\prime \prime E} 32^{\circ} 45^{\prime} 0^{\prime \prime E} 32^{\circ} 50^{\prime} 0^{\prime \prime E} 32^{\circ} 55^{\prime} 0^{\prime \prime E}$}
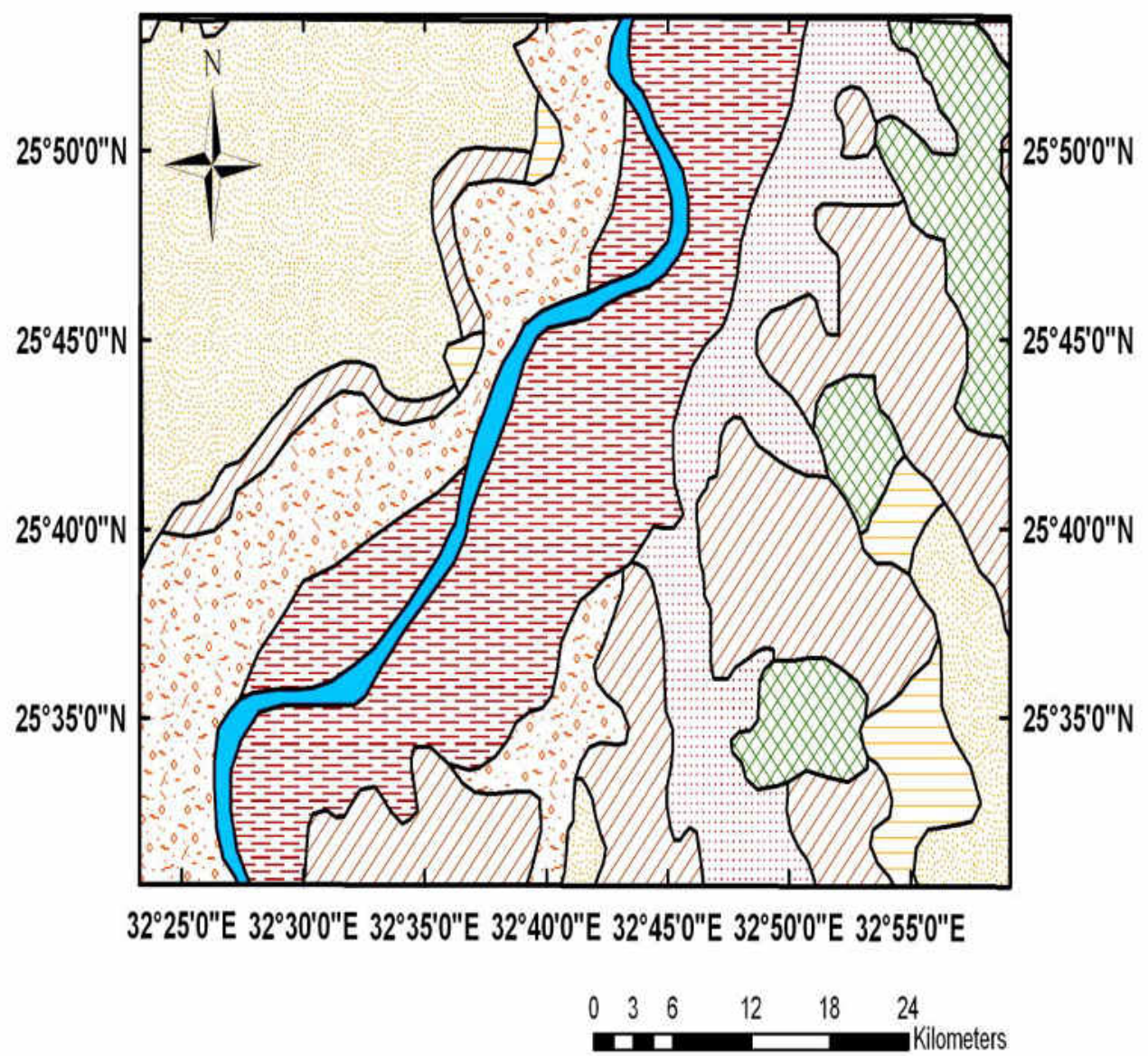

\section{Legend}

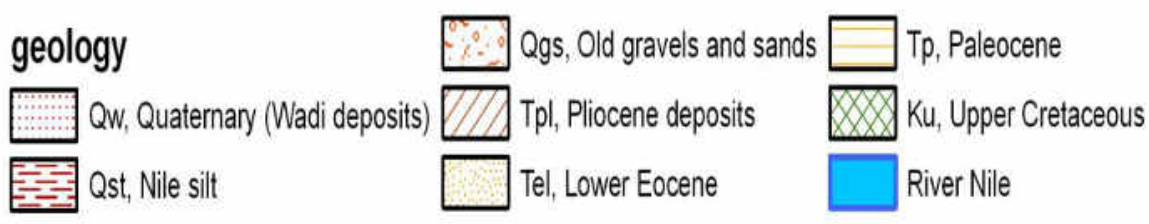

Fig. 2a Geologic map of study area (modified from GSE, 1979). 


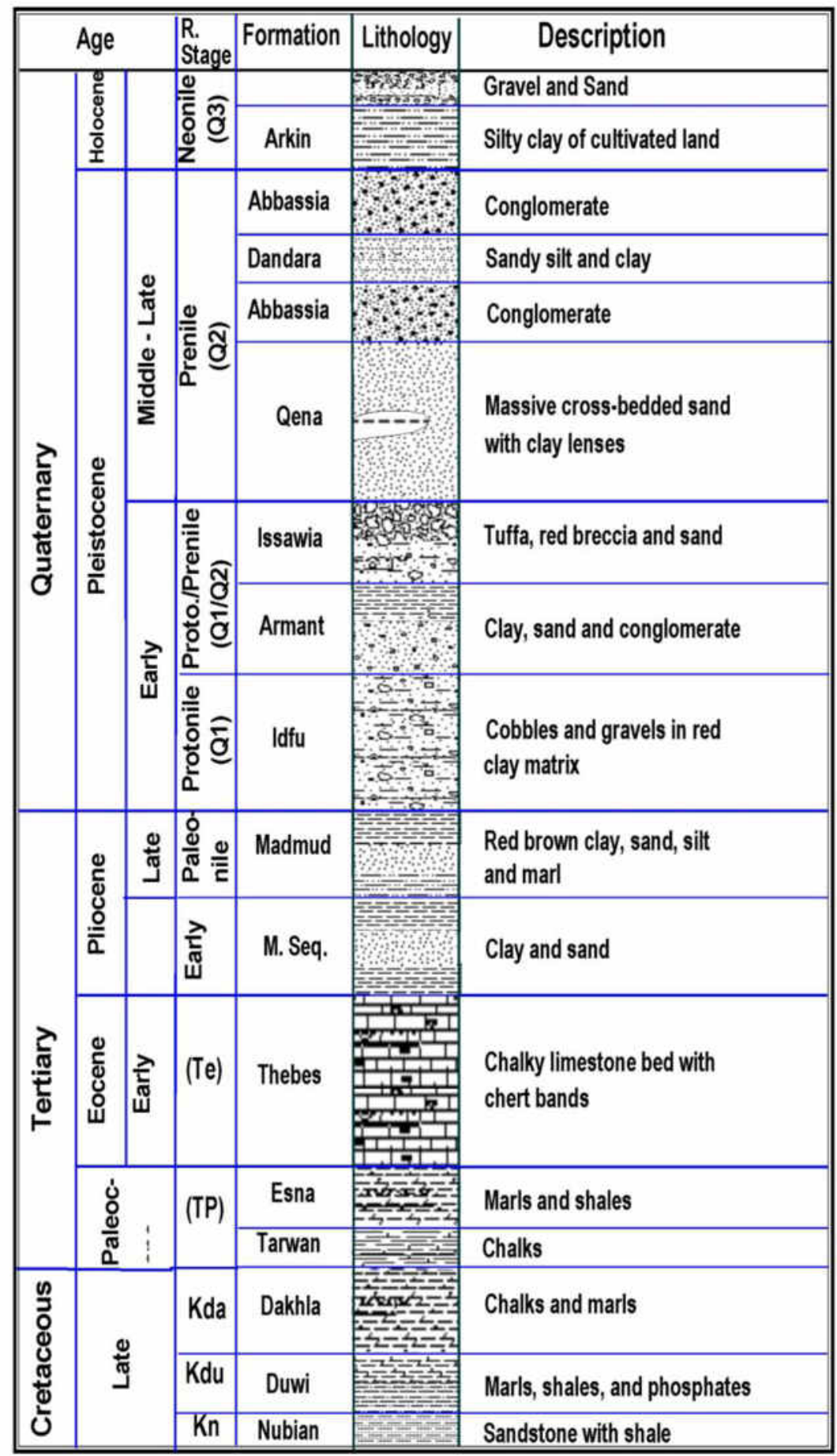

Fig. 2b Composite stratigraphic column of Luxor area (after El-Hossary 1994, in Ismail et al 2005) 

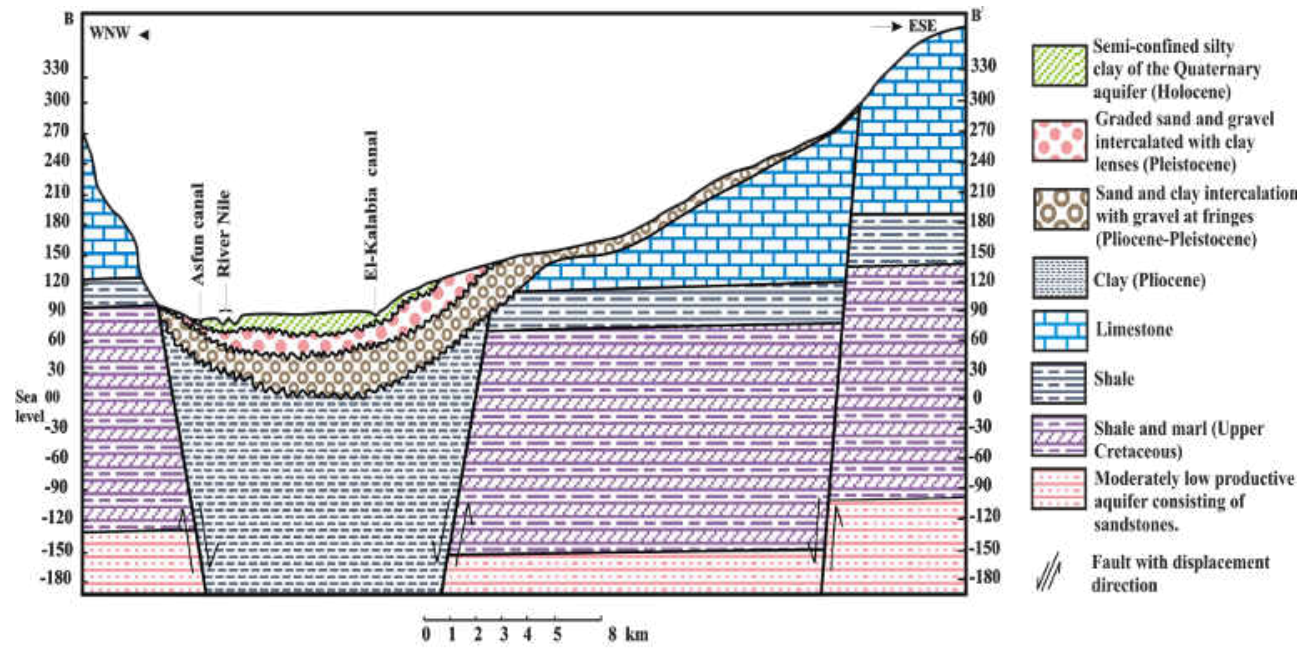

Fig. 3 Hydrostratigraphic cross section at Luxor area (modified from RIGW, 1997b).

\section{DETERIORATION OF ARCHAEOLOGICAL SITES}

Many studies carried out to investigate the deterioration of archaeological sites in Upper Egypt such as the works of SWECO (1982), Abd El Hady (1986, 1988, 1993, 1995), Ismaeil (1999), Ismaeil and Abdel Moneim (1999), El-Gohary (2000), Wüst (2000), Wüst and McLane (2000), Ahmed (2003) and Ismail et al 2005.

In general, deterioration of archaeological sites includes loss of the surface layers of sandstone which carry moral paintings, soil salinization, crystallization of salts in walls and columns, stone bleeding, destruction of wall paintings and texts, decreasing the durability of monumental sandstones and seepage of capillary groundwater.

Drainage in the Nile Valley was not a problem before the construction of High Dam. The prevailing hydrologic conditions were such that land drainage and salt balance were attained naturally after cessation of the annual floods. Furthermore, groundwater levels increased after the high dam due to the increase in surface water deliveries and applied irrigation water and lack of a suitable drainage network. As a result, the water table has built up continuously, causing drainage problems and evaporation from the capillary fringe, in turn leading to salinization problems (Kotb et al. 2000; Ahmed 2003).

\section{LAND USE CHANGE}

Three sets of imagery were used for accomplishing this study; Landsat MSS (Multi Spectral Scanner), Landsat Thematic Mapper (TM), and Enhanced Thematic Mapper (ETM+) images acquired on years 1972, 1984 and 2000 respectively. The landsat images were georefernced to UTM coordinate system, zone 36 North based on topographic maps of study area. The three sets of imagery were used to investigate the land use change over the selected time period. Erdas Imagine 9 and ArcGIS 9.2 were used for analysis of data and visualization of results. 
In this part, supervised and unsupervised classification were used for analysis of change of agriculture and urbanization through the time period from year 1972 to 2000 .

\section{TOPOGRAPHY AND DEM ANALYSIS}

Topography of study area has a vital role in deterioration of archaeological sites. The study area is located on the alluvial plains which slope generally to the north and west and represented by the cultivated younger plain occupying the central part of the Nile Valley and older reclaimed plain at the valley fringes. Topography determines the direction of seeping water through ground surface and soil profile. Digital elevation model (DEM) of study area is obtained from the Shuttle Radar Topography Mission (SRTM) data and used in analyzing the topographic zones in the study area.

\section{RESULTS}

The main land uses at Luxor area include agriculture and urbanization which considered the main deteriorating factors on archaeological sites (Fig. 4). The two land use classes facilitate the seepage of drainage water underneath the temples and promoting the deterioration of foundations. Agriculture and urbanization in the study area were changed significantly through the studied period 1972 to 2000 (Figs. 5, 6).

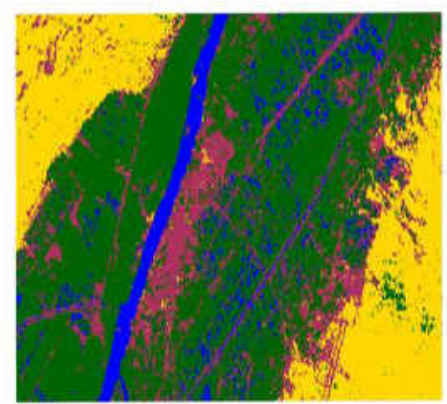

Year 1972

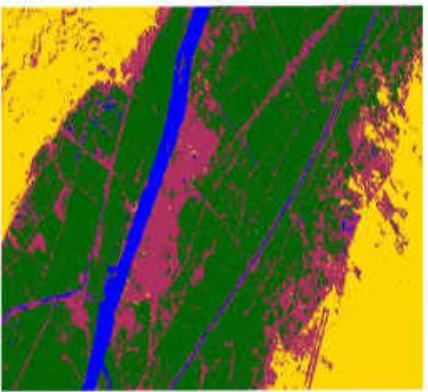

Year 1984

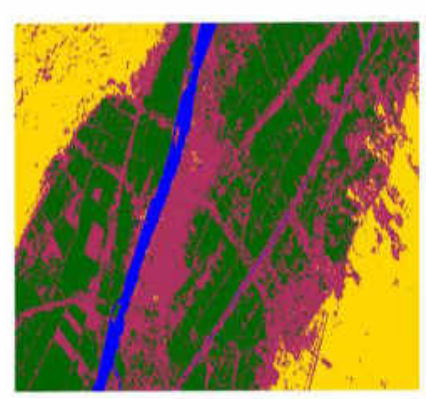

Year 2000

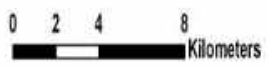

\section{Legend}

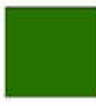

Agricultural lands

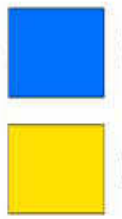

Water

Desert areas

Fig. 4 Land use classes at Luxor area from year 1972 to 2000. 


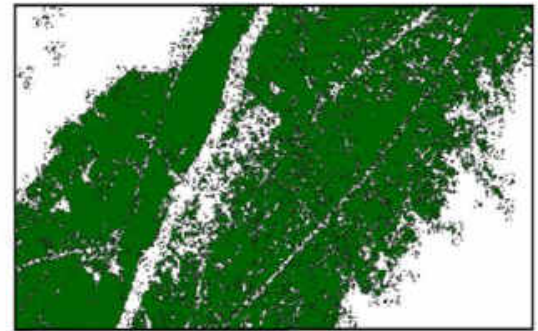

Year 1972

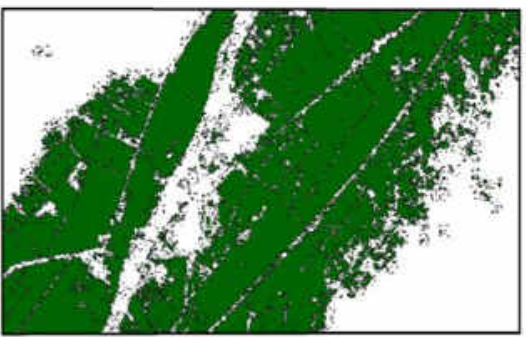

Year 1984
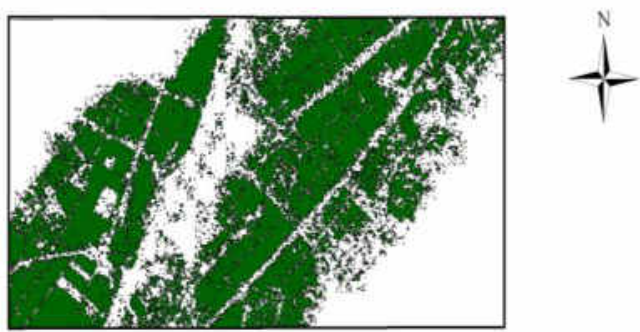

$\begin{array}{llll}0 & 1.25 & 2.5 & 5 \\ & & & \end{array}$

\section{Legend}

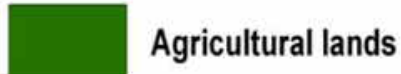

Background

Fig. 5 Agriculture at Luxor area during years 1972, 1984 and 2000.

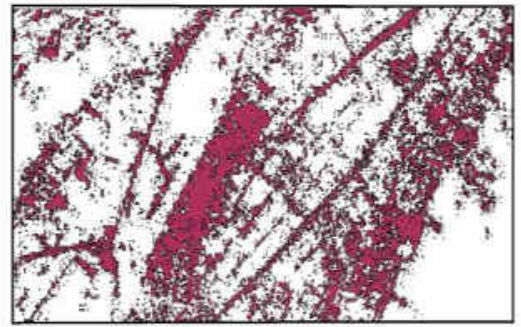

Year 1972

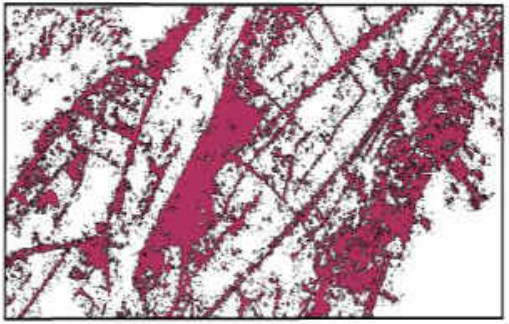

Year 1984

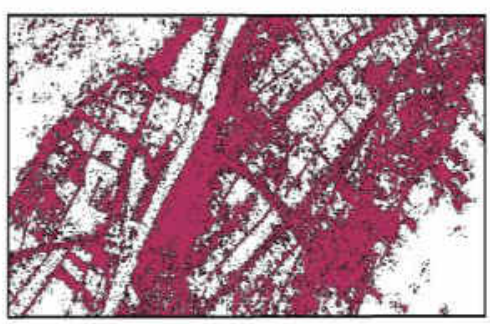

Year 2000

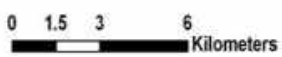

\section{Legend}

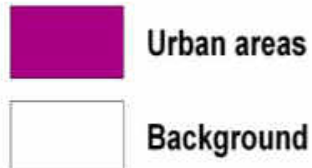

Fig. 6 Urbanization at Luxor area during years 1972, 1984 and 2000. 


\section{Change of agriculture}

Agricultural lands were decreased slightly from year 1972 to 1984 . The greatest change was observed from year 1984 to year 2000 were the agricultural lands were decreased from $78808400 \mathrm{~m}^{2}$ at year 1984 to $58098400 \mathrm{~m}^{2}$ at year 2000. Figure 7 shows the change in agriculture at Luxor area from year 1972 to 2000. The red color areas (pixels) show the decreased areas of agriculture and the green color areas shows the increased areas.

\section{Urbanization}

Urbanization activities are the main active land use class at Luxor area. The results showed that urbanization is in a continuous change during the studied period of time. Figure 8 shows the change in urbanization at Luxor area from year 1972 to 2000. The red color areas (pixels) show the decreased areas of urbanization and the green color areas shows the increased areas. Urbanization increased from year 1972 to 1984 . The greatest change was observed from year 1984 to 2000 where urban encroachment affected the agricultural lands were urbanization increased from $35318100 \mathrm{~m}^{2}$ at year 1984 to $53155600 \mathrm{~m}^{2}$ at year 2000 .

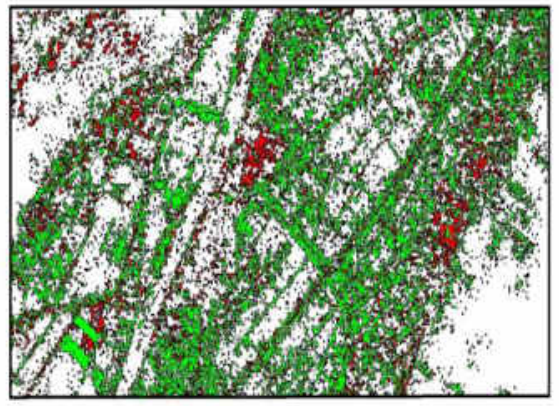

Year 1972 - 1984

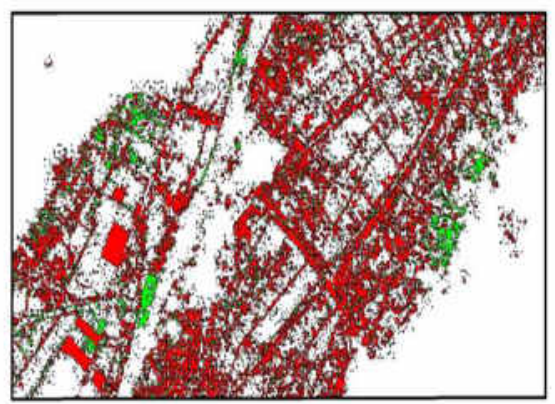

Year $1984-2000$
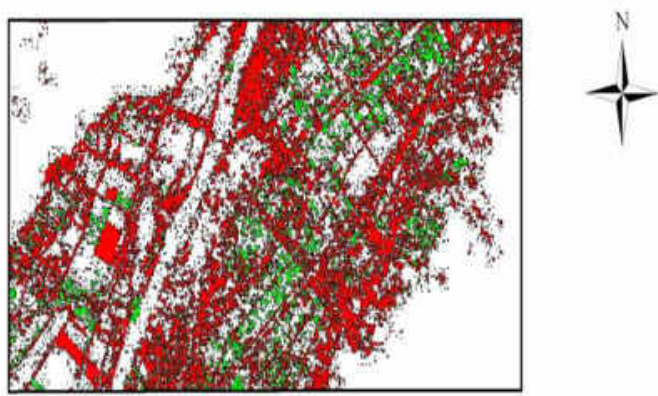

Year $1972-2000$

$01.252 .5 \quad 5$

Kilometers

\section{Legend}

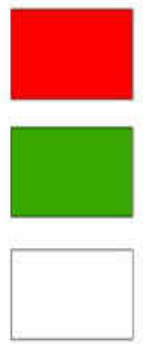

Decreased

Increased

Background

Fig. 7 Change in agriculture at Luxor area from year 1972 to 2000. 


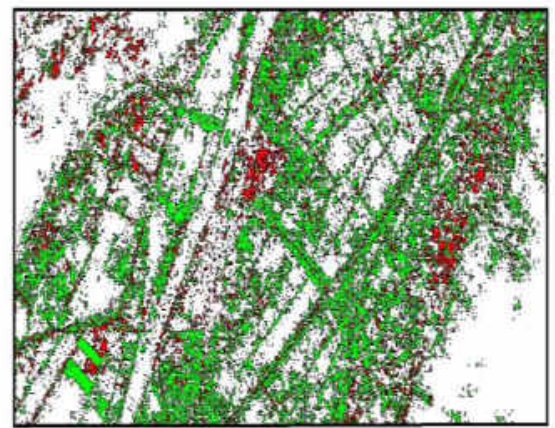

Year 1972 - 1984

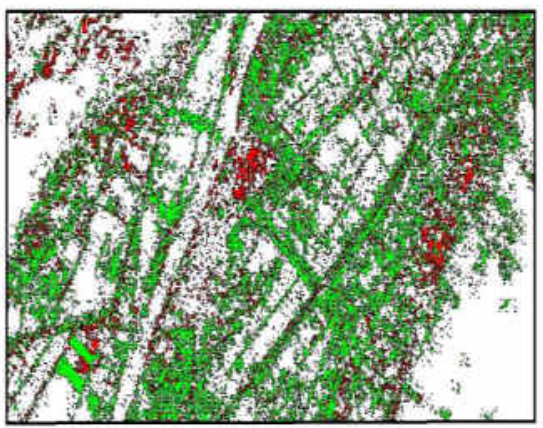

Year $1984-2000$
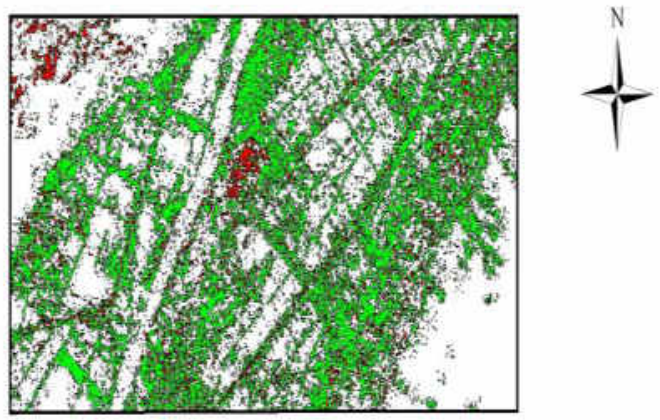

Year $1972-2000$

$01.252 .5 \quad 5$

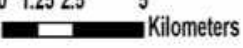

Legend

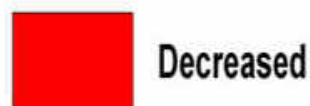

Increased

Background

Fig. 8 Change in urbanization at Luxor area from 1972 to 2000.

Analysis of landsat imagery indicated that the agricultural areas are continuously decreased and replaced by urban areas (Fig. 9). From year 1984 to year 2000 , the agricultural areas decreased from $78.80 \mathrm{~km}^{2}$ to $58.09 \mathrm{~km}^{2}$, and the urban areas increased from $35.32 \mathrm{~km}^{2}$ to $53.15 \mathrm{~km}^{2}$ (Table 1).

Table (1): Change in agriculture and urbanization from year 1972 to 2000.

\begin{tabular}{|l|c|c|c|}
\hline Year & 1972 & 1984 & 2000 \\
\hline Agriculture $\left(\mathrm{km}^{2}\right)$ & 79.29 & 78.80 & 58.09 \\
\hline Urbanization $\left(\mathrm{km}^{2}\right)$ & 25.64 & 35.31 & 53.15 \\
\hline
\end{tabular}

The results indicated that Luxor and Karnak temples are situated in a high plantation and farming zone, thus wastewater is accumulated through nearby trenches. The case is worsened by additional input of seepage water from urbanization sites (Fig. 10). These monuments are made from stone which has the capillary effect that causing a large amount of water to be taken into the main foundations. 


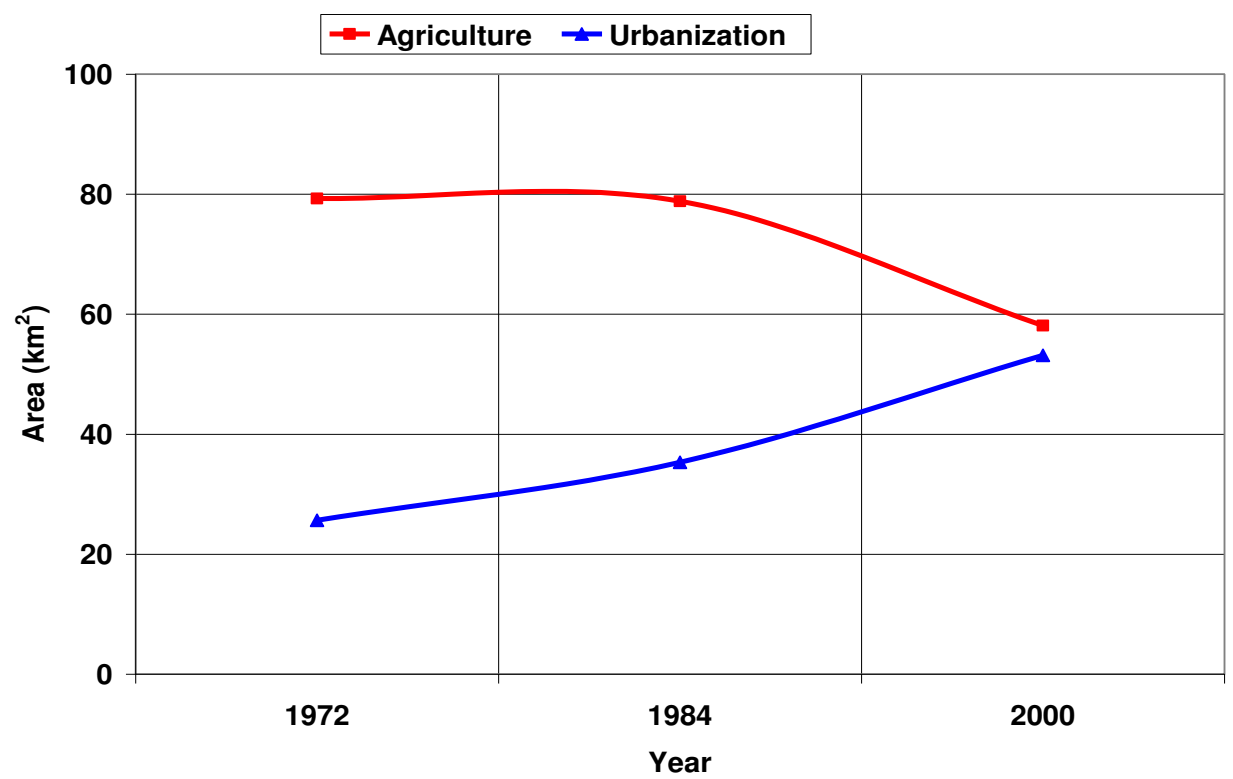

Fig. 9 Change in agriculture and urbanization at Luxor area during years 1972, 1984 and 2000.

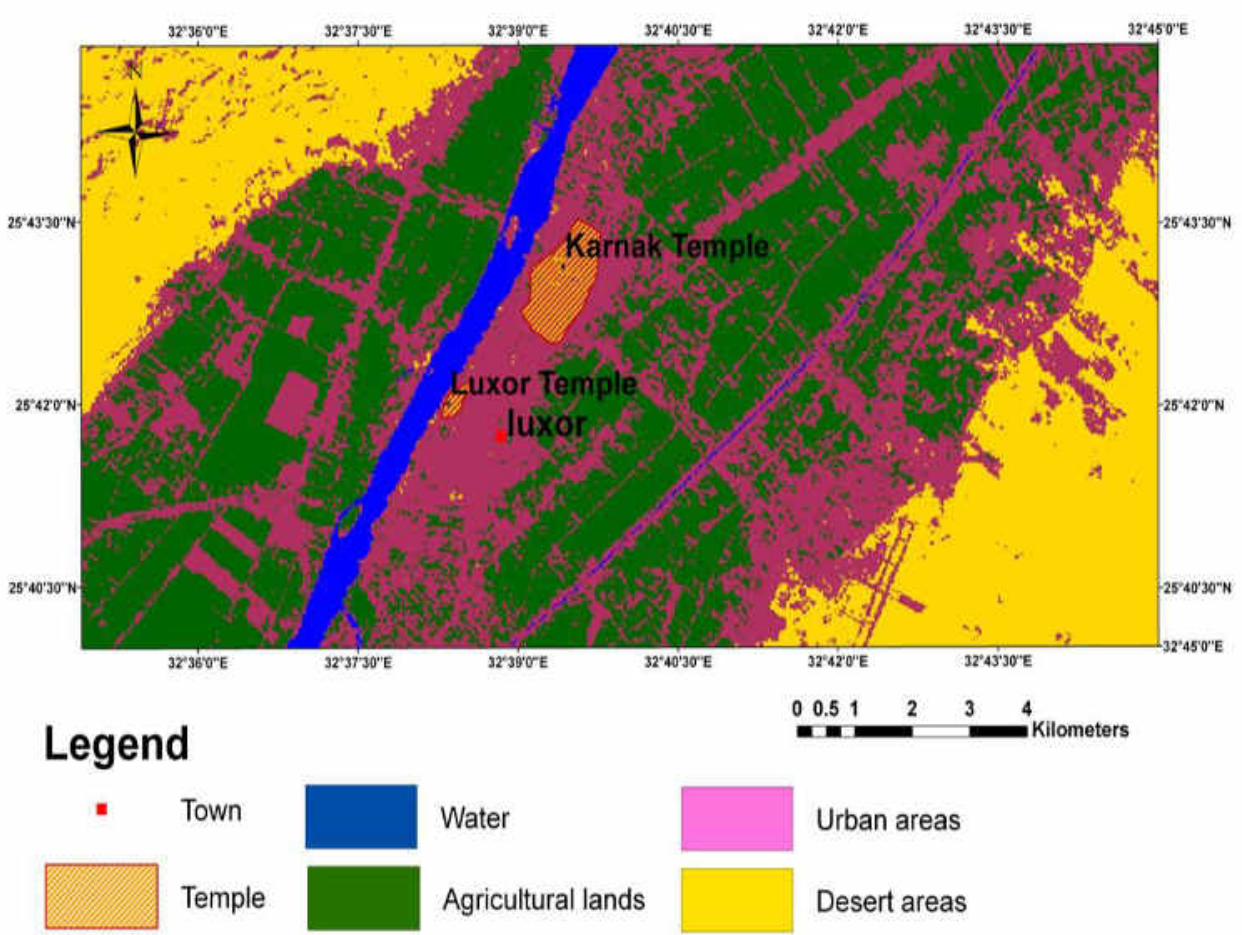

Fig. 10 The Karnak and Luxor temples are located in a highly planted and urbanized area. 
Analysis of the digital elevation model of the study area (DEM) revealed that the area is characterized by different elevation zones reaching $\sim 504 \mathrm{~m}$ at the eastern and western boundaries and $\sim 67 \mathrm{~m}$ at the temples (Fig. 11). This topographic condition promotes seepage of water to the foundations.

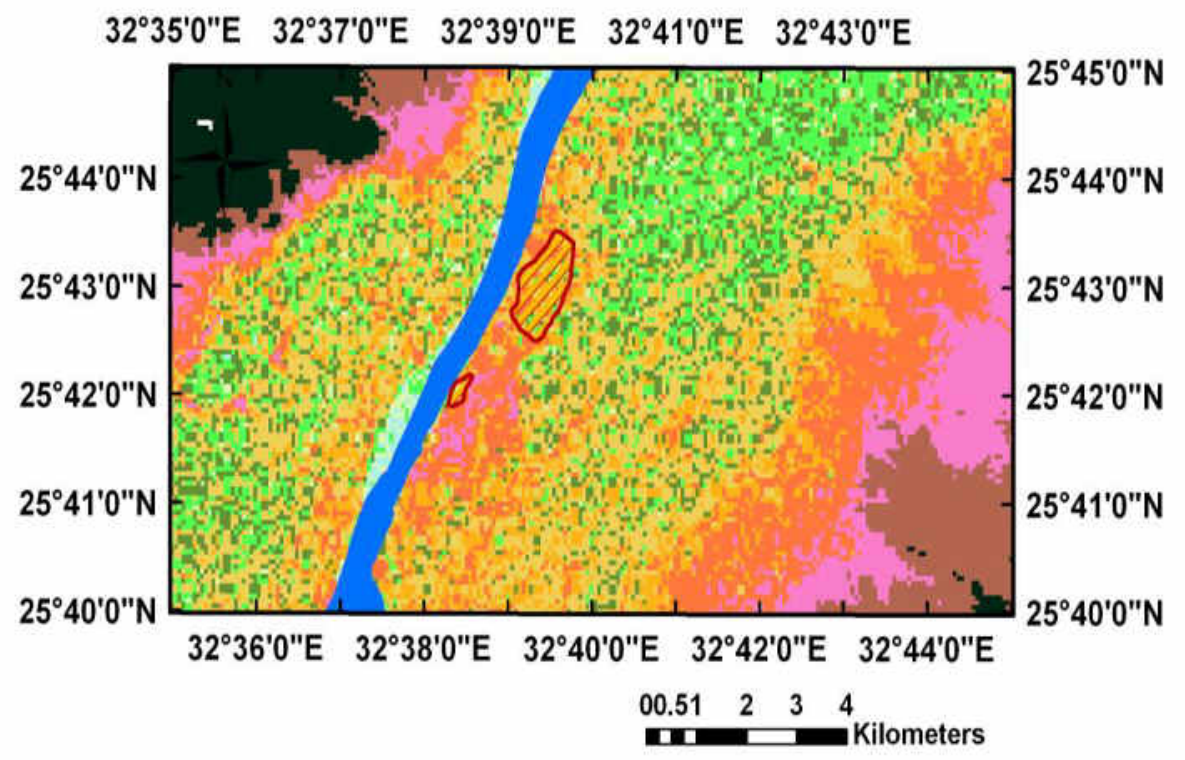

Legend

\begin{tabular}{|c|c|c|c|}
\hline Temple & Elevation (m.a.s.l) & $77.28-78.99$ & $87.56-97.84$ \\
\hline \multirow[t]{3}{*}{ River Nile } & $67-73.85$ & $78.99-80.70$ & $97.84-120.12$ \\
\hline & $73.85-75.56$ & $80.70-82.42$ & $120.12-504$ \\
\hline & $75.56-77.28$ & $82.42-87.56$ & \\
\hline
\end{tabular}

Fig. 11 Karnak and Luxor temples are located at the lower elevations.

\section{DISCUSSION}

Luxor area is a higtorical and an active part of the Nile Valley. Land use at Luxor area includes agriculture and urbanization which changed dramatically from year 1972 to year 2000. This change has its impact on the archaeological sites, especially Karnak and Luxor temples.

Karnak and Luxor temples are currently threatened by seepage water from irrigation system and sewage water from the increasingly urban areas. The building stones of these temples absorb water and react with the climatic conditions leading ultimately to deterioration of the building stones. Three factors are leading to deterioration of these temples; topography where the temples are located at the lower elevation zones, seepage from the irrigation system where the area surrounding the temples are highly planted, and the increased seepage from the increasing urban areas. 
This situation is not promising and urgent measures should be taken to avoid the probable future disintegration of the monuments.

It is worse mentioning that any effort for restoration of archaeological sites at the study area will be not effective without re-working the balance between the land use change to avoid the accompanied hazards of groundwater and wastewater seepage.

It is recommended to study the amount of seepage water from the different land use classes that could affect the study area. Management of land use in the study area should be considered. Monitoring of land use change and seepage of water should be applied and used for decision making processes.

\section{REFERENCES}

1. 1 -El Hady, M. and Ismaeil, M. B. (1995): The effect of environmental conditions on deterioration of monuments in Assiut and Upper Egypt. $1^{\text {st }}$ International Conference on Environment and Development in Africa, Assiut, 2124 October, 1995.

2. Abd El Hady, M. M. (1986): Durability of limestone and sandstone monuments in the atmospheric conditions in Egypt. Ph. D. Thesis, Warsaw University, Poland.

3. Abd El Hady, M. M. (1988): Durability of monumental sandstone in Upper Egypt. Preservation and protection. Preceeding of international symposium organized by the Greek National Group of IAEG, Athens 19-23 Sep. 1988.

4. Abd El Hady, M. M. (1993): The structural damage of the building stones as effects of the physico-chemical factors, second course on: stone material in monuments diagnosis and conservation, pp. 101-113, Crete.

5. Abd El Hady, M. M. (1995): Geotechnical problems of monumental stones, third course on the conservation project, pp. 72-80 Gargnagno.

6. Ahmed AA (2003): The impact of hydrogeological conditions on the archaeological sites at some localities between Qena and Aswan, Egypt. Ph. D. Thesis, Geology Department, Faculty of Science, South Valley University, Sohag, Egypt.

7. Awad, G. H. and Ghobrial, M. G. (1965): Zonal stratigraphy of the Kharga Oasis. Geol. Surv. Egypt, Paper 34, 77p.

8. Awad, M. A.; El Arabi, N. E.; Mokhtar, S. and Hamza (1997): Use of solute chemistry and isotopes to identify sources of groundwater recharge in the Nile Aquifer Sysytem, Upper Egypt. Ground Water, V. 35, N2, p. 223 (6).

9. Baines, J. and Malek, J. (2000): Cultural Atlas of Ancient Egypt. Checkmark Books, Rev. Ed., 240 p.

10. Beadnell, H. J. (1905): The topography and geology of Faiyum province of Egypt. Survey Dept., Egypt, $101 \mathrm{p}$.

11. Butzer, K. W. and Hansen, C. L. (1968): Desert and River in Nubia. University of Wisconsin Press, Madison, $562 \mathrm{p}$.

12. Cuvillier, J. (1938): La Serie Sedimentaire a l'est de Khizam (Hute-Egypte), 151$153 \mathrm{pp}$.

13. El Hossary, M. (1994): Hydrogeological and hydrochemical studies on Luxor area, Southern Egypt. B. Sc. Thesis, Faculty of Science, Ain Shams Univ., Cairo, Egypt. 
14. El-Gohary, M. A. (2000): Effect of groundwater on stones used in some Egyptian Temples in Upper Egypt with scientific and application methods for its conservation and maintenance. Ph. D. Thesis, Conservation Dept., Fac. Arts, South Valley Univ., Sohag, Egypt.

15. El-Naggar, Z. R. (1963): The geology and stratigraphic paleontology of the EsnaIdfu region, Nile Valley, Egypt. U.A.R. Ph.D. Thesis, V.C.W. Aberystwyth, U.K.

16. El-Naggar, Z. R. (1966): Stratigraphic and planktonic foraminifera of the Upper Cretaceous-Lower Tertiary succession in the Esna-Edfu region, Nile Valley, Egypt. U. A. R. Bull. Br. Mus. Nat. Hist., Ser., Geol., V. 2, p. 1-291.

17. El-Naggar, Z. R. (1968): Stratigraphy and classification of type of Esna Group of Egypt. Reply. Amm. Assoc. Petrol. Geol. Bull., V. 52, p. 1794-1798.The geology and stratigraphic paleontology of the Esna-Idfu region, Nile Valley, Egypt. U.A.R. Ph.D. Thesis, V.C.W. Aberystwyth, U.K.

18. Farrag, A. A. (1982): Hydrogeological studies on the Quaternary water bearing sediments in the area between Assiut and Aswan. M. Sc. Thesis, Geol. Dept., Fac. Sci. Assiut Univ., Egypt, 99 p.

19. Ghanem et al. (1970): Stratigraphy of the phosphate-bearing Cretaceous and Paleocene sediments of the Nile Valley between Idfu and Qena: In O. Moharram et al. (eds.), studies on some mineral deposits of Egypt. Geol. Surv. Egypt, p. 109134.

20. Ghorab, M. A. (1956): A summary of a proposed rock stratigraphic classification for the Upper Cretaceous rocks in Egypt. Geol. Soc. Egypt, Cairo, Egypt.

21. GSE "Geological Survey of Egypt" (1979): Geological map sheet NG-36, scale $1: 1,000,000$.

22. Helmy, I. and El Shahat, A. (1996): Groundwater impact on Luxor Temple. The first International conference of Control of rising groundwater problem in urbanized areas (5-6 November, 1996), Faculty of Engineering, Mansoura University, Egypt, p. 147-157.

23. Ismaeil, M. B. and El-Habaak, G. (1995): Durability characteristics of some diorite and granodiorite monuments. Bull. Fac. Arts, No. 5, Part 2, pp. 59-85.

24. Ismaiel, M. B. (1999): Study of the deterioration phenomena in the Ptolemic temple of Dendera, Egypt. Bull. Fac. Eng., Assiut Univ., V. 27, No. 1, p. 243-262.

25. Ismaiel, M. B. and Abdel Moneim, A. A. (1999): Environmental deterioration of Karnak temples, Luxor, Upper Egypt. Bull Fac. Eng., Assiut Univ., V. 27, No. 1, pp. 273-302.

26. Ismail, A.; Anderson, N. L.; Rogers, J. D. (2005): Hydrogeophysical Investigation at Luxor, Southern Egypt. JEEG, Volume 10, Issue 1, p. 35-49.

27. Kamel, E. R. (2004): Geology of Luxor area and its relationship to groundwater uprising under the Pharaohs Temples. M. Sc. Thesis, Aswan Faculty of Science, South Valley University, Egypt.

28. Kotb, T. H.; Watanabe, T.; Ogino, Y.; Tanji, K. (2000): soil salinization in the Nile delta and related policy issues in Egypt. Agricultural Water Management, 43, p. 239-261.

29. Philobbos, E. R. (1969): Geology of Phosphates of the Nile Valley. Ph. D. Thesis, Geol. Dept., Assiut Univ., Egypt, 448 p.

30. RIGW (1997a): Study of seepage reasons and solutions in Temple of Karnak. Internal Report. 
31. RIGW (1997b): Hydrogeological maps of Egypt, scale 1:100,000. Water Research Center, Ministry of Public Works and Water Resources, Egypt.

32. Said, R. (1960): Planktonic foraminifera from the Thebes Formation, Luxor, Egypt. Micropaleontlogy, V. 6, 227-286 p.

33. Said, R. (1961): Planktonic foraminifera from the Thebes Formation, Luxor, Egypt. Micropaleontlogy, V. 6, p. 227-286.

34. Said, R. (1962): The geology of Egypt. Elsevier, Amesterdam and NewYork.

35. Said, R. (1981): The geological evolution of the River Nile. Springer Verlag. New York, Heidelberg. Berlin, $151 \mathrm{p}$.

36. Saleh, A. S. (1982): Study of the reconstruction of the Beard of the Sphinx, Part 1, E. A. O.

37. Saleh, A. S. (1983): Salt problems in Egyptian Monuments. Report presents to Egyptian Antiques Organization, Cairo, Egypt.

38. Selim, S. A.; Khedr, E. S.; Falasteen, A. W. \& Kamel, E. R. (2000): Reasons of local rise in groundwater level at Luxor city area, Upper Egypt. $5^{\text {th }}$ International Conference on the Geology of the Arab World, Cairo University, Feb 2000, p. 901910.

39. Shahin M (1991): Assessment of groundwater resources in Egypt. IHE Report Series no. 23. The Netherlands: International Institute for Hydraulic and Environmental Engineering.

40. SWECO (1982): Effects of groundwater on pharaonic monuments. reconnaissance study.

41. Wendorf, F. and Schild, R. (1976): Prehistory of the Nile Valley. Academic Press, New York and London, $404 \mathrm{p}$.

42. Wüst, R. A. (2000): The origin of soluble salts in rocks of the thebes mountains, Egypt: The damage potential to Ancient Egyptian Wall Art. Journal of Archaeological Science, V. 27, 1161-1172 pp.

43. Wüst, R. A. and McLane, J. (2000): Rock deterioration in the Royal Tomb of Seti, Valley of the Kings, Luxor, Egypt. Engineering Geology 58, p. 163-190.

44. Youssef, M. I. (1949): Stratigraphical studies in Kosseir area. Ph. D. Thesis, Fac. Sci., Alex. Univ.

45. Youssef, M. I. (1954): Stratigraphy of Gebel Oweina section, near Esna, Upper Egypt. Bull. Inst. Desert, Egypt, V. 4, p. 83-93p.

46. ECHO "Egyptian Cultural Heritage Organization" (2006): Egypt's cultural heritage under threat of destruction. http://www.e-c-ho.org/News/LatestNews5.htm 


\section{التغير فى استخدامات الاراضى وتلف المعابد الاثرية فى مصر العليا \\ ايمن عبد الحمبد احمد والاصد \\ قسم الجيولوجيا، كلية العلوم، جامعة سوهاج اهمبد}

تتأثز المعابد الاثرية فى مصر العليا فى الوقت الحالى بالتغيرات البيئية والتى تشمل ارتفاع مناسيب المياه الجوفية وتسرب مياه الصرف الصحى والزراعى من المناطق الزراعية والمناطق السكنية المحيطة. وترجع هذه المشاكل بصفة اساسية الى تغير استخدامات الاراضى منذ انشاء السد العالى منذ عام 1968. يتمنل التغير فى استخدامات الاراضى فى انساع رقعة الاراضى الزراعية بوادى النيل والتوسع الحضرى. يعتمد البحث الحالى على استخدام تقنيات نظم المعلومات الجغرافية والاستشعار عن بعد فى لهى تحديد التغير فى استخدامات الاراضى فى مصر العليا منذ انثاء السد العالى. فقد اعتمدت الدراسة على استخدام المرئيات الفضائية والتى تغطى الفترة الزمنية منذ عام 1972 الى 1900. الدراسة تغيرات جوهرية فى الاستخدامات الزراعية والحضرية خلال الفترة الزمنية المختارة. فقد حدث نقص فى الرقعة الزراعية منذ عام 1984 الى 2000، بينما حدثت زيادة فى الاستخدامات الحضرية منذ عام 1972 حتى 2000. وقد صاحب هذه التغيرات فى استخدامات الاراضى تغيرات بيئية متمنلة فى تسرب مياه الصرف الزراعى والصحى الى منطقة المعابد. وهذا الوضع الراهن يتطلب ادارة المنطقة ووضع الحلول والبدائل لعمل نوازن بين التغيرات فى استخدامات الاراضى والمخاطر المصاحبة. 